\title{
Jeremy Bentham and the Origins of Legal \\ Positivism \\ Philip Schofield
}

\subsection{Hart and Bentham}

H. L. A. Hart is generally recognised as the most influential twentiethcentury exponent of the doctrine of legal positivism. According to Hart, Jeremy Bentham (1748-1832), the philosopher and reformer, 'opened the long positivist tradition in English jurisprudence'. ${ }^{1}$ Stephen Perry points out that Hart's legal positivism contains two doctrines, namely substantive and methodological legal positivism, though Hart himself did not explicitly distinguish them. The former consists in the claim that there is no necessary connection between morality and the content of law and the latter in the claim that there is no necessary connection between morality and legal theory. ${ }^{2}$ Hart in effect attributed both doctrines to Bentham when referring to 'Bentham's sharp severance ... between law as it is and law as it ought to be and his insistence that the foundations of a legal system are properly described in the morally neutral terms of a general habit of obedience.' ${ }^{3}$ Bentham's view that there was no necessary connection between law and morality (his 'sharp severance ... between law as it is and law as it ought to be') and his description of a legal system in 'morally neutral terms' were equivalent to Hart's substantive and methodological doctrines respectively. Hart, moreover, indicated that Bentham's methodological legal positivism had been subservient to his substantive legal positivism: '[Bentham] insisted on a precise, morally neutral vocabulary for use in the discussion of law and politics as part of a larger concern to sharpen men's awareness ... of the distinction between what is and what ought to be. ${ }^{4}$

${ }^{1}$ Hart 1982: 53. ${ }^{2}$ See Perry 2001: 311-54. ${ }^{3}$ Hart 1982: 53.

${ }^{4}$ Hart 1996: lxxxv. See also Hart 1982: 28: “[A]mong Bentham's many claims to be an innovator none is better founded nor, I think, more important than his insistence on a precise and so far as possible a morally neutral vocabulary for use in the discussion of 
According to Hart, therefore, Bentham's substantive legal positivism divided the subject of jurisprudence into two branches, law as it is and law as it ought to be, while his methodological legal positivism was concerned with the elucidation of key terms when describing law as it is - in other words, Bentham began by distinguishing between what is (fact) and what ought to be (value), and then, within the field of fact, the explanatory task was undertaken in morally neutral terms. As we shall see, the distinction between law as it is and law as it ought to be - between what he termed expository and censorial jurisprudence respectively - and, within expository jurisprudence, the elucidation of such leading terms as were found in all legal systems were prominent features of Bentham's legal theory. To this extent, Hart's identification of Bentham as the founder of legal positivism appears plausible. Yet it is doubtful that the historical Bentham is properly described as either a substantive or a methodological legal positivist, since the principle of utility permeated his thought in such a way that the separation of fact and value and the notion of moral neutrality would have made little sense to him. ${ }^{5}$ In what follows, the focus will be on Bentham's early writings on jurisprudence dating from between 1775 and 1782, on which Hart himself mainly drew and which has formed the basis for much of the relevant scholarship. ${ }^{6}$ Such a focus seems reasonable given the fact that, throughout his long career, Bentham remained committed to the basic positions that he had established in these formative years.

\subsection{Expository and Censorial Jurisprudence}

Bentham distinguished between 'law as it is' and 'law as it ought to be' in A Fragment on Government (1776), his first major published work. This work emerged from a more ambitious enterprise entitled 'A Comment on the Commentaries', which was intended as a detailed examination of the 'Introduction' to William Blackstone's Commentaries on the Laws of England (1765-9), which had quickly established itself as the standard account of English law and, therefore, presented a suitable target for

law and politics ... The terms that Bentham uses to define law are all flatly descriptive and normatively neutral'.

${ }^{5}$ See further Schofield 2010.

${ }^{6}$ For an account of the development of Bentham's legal theory in the 1770s and early 1780s, see Lieberman 1989; for a wide-ranging reconstruction, see Postema 1986. 
someone trying to establish his reputation as a legal author. Bentham eventually abandoned 'A Comment on the Commentaries' without publishing it, ${ }^{7}$ but he detached a critique of a short passage of Blackstone's on government and published it on its own account as A Fragment on Government. ${ }^{8}$ In explaining the reasons for "that war which, for the interests of true science, and of liberal improvement, I think myself bound to wage against' Blackstone's Commentaries, Bentham pointed to the 'two characters, one or other of which every man who finds any thing to say on the subject of Law, may be said to take upon him; - that of the Expositor, and that of the Censor'. The role of the former, in explaining what the law is, was to discover facts, while the role of the latter, in observing what the law ought to be, was to discuss reasons. 'That which is Law', noted Bentham, 'is, in different countries, widely different: while that which ought to be, is in all countries to a great degree the same. The Expositor, therefore, is always the citizen of this or that particular country: the Censor is, or ought to be the citizen of the world.' 9

Bentham noted that Blackstone's task, given that his 'professed object was to explain to us what the Laws of England were', was that of the expositor, and had he restricted himself to that task, there would have been no reason to criticise him. Not satisfied, however, with this 'humbler function', he had gone on 'to give reasons in behalf of' the institutions and practices of English law. Bentham lamented that more praise was given to someone who defended old established institutions than to someone who censured them when wrong. Unless a system was censured, it would never be improved, while a determination to approve of everything that existed and disapprove of nothing would 'stand as an effectual bar to all the additional happiness we can ever hope for; pursued hitherto would have robbed us of that share of happiness which we enjoy already'. Bentham asked, 'Under a government of Laws, what is the motto of a good citizen?' and answered, 'To obey punctually; to censure freely.' 10

${ }^{7}$ For the provenance of the work, see Bentham 1977: Editorial Introduction xxiv-xxviii.

8 Bentham 1977: Editorial Introduction xxix-xxx.

9 Bentham 1977: 397-8. In his mature writings on codification, Bentham argued that 'universally applying circumstances' were far more important and far more common than 'exclusively applying circumstances', and that the laws that were best for one country would, therefore, very often be best for every other: see Bentham 1998: 291-3.

10 Bentham 1977: 399-400. 
Commenting on a passage in which Blackstone had stated that the supreme power in a state had a duty to make laws, ${ }^{11}$ Bentham complained:

He sets out with the word 'duty' in his mouth; and, in the character of a Censor, with all due gravity begins talking to us of what ought to be. 'Tis in the midst of this lecture that our Proteus slips aside; puts on the historian; gives an insensible turn to the discourse; and, without any warning of the change, finishes with telling us what is. Between these two points, indeed, the is, and the ought to be, so opposite as they frequently are in the eyes of other men, that spirit of obsequious quietism that seems constitutional in our Author, will scarce ever let him recognize a difference. $^{12}$

This passage echoes and at the same time reverses David Hume's complaint about authors who moved from propositions containing 'is' and 'is not' to propositions containing 'ought' and 'ought not', but without explaining how they had derived the latter from the former. ${ }^{13}$ For Bentham, Blackstone had moved from propositions concerning what ought to be to propositions concerning what is. He took Blackstone's statement, made in the context of the English law of heresy, that 'every thing is now as it should be ${ }^{, 14}$ as typifying the conservative mentality.

While Blackstone's general purpose was 'to inculcate unreserved submission' to authority, noted Bentham, he had been led into an 'inconsistency' through his adoption of the natural law formula lex iniusta non est lex, which again confounded the two roles of expositor and censor but with a very different outcome. In his Commentaries, Blackstone had asserted the primacy of natural law over positive law:

This law of nature, being co-eval with mankind and dictated by God himself, is of course superior in obligation to any other. It is binding over all the globe, in all countries, and at all times: no human laws are of any validity, if contrary to this; and such of them as are valid derive all their force, and all their authority, mediately or immediately, from this original.

While there were many areas of conduct where the natural law was 'indifferent' and the human legislator could pass such laws as were found to be convenient, continued Blackstone, no human legislator could make right what God had willed to be wrong or make wrong what God had willed to be right. If a human law required or allowed us to disobey the divine law,

\footnotetext{
11 See Blackstone 1765-9: i. 52-3. ${ }^{12}$ Bentham 1977: 498. ${ }^{13}$ See Hume 2007: i. 302.

14 Blackstone 1765-9: iv. 49.
} 
we were 'bound to transgress' the human law. ${ }^{15}$ In Bentham's view, this was a 'dangerous maxim' in that the 'law of nature' was 'nothing but a phrase' and any appeal to it merely represented an appeal to the likes and dislikes - founded on the interests - of the person making the appeal. No government could exist under such conditions. In deciding whether to resist or to obey government (Bentham was writing at the onset of the American War of Independence when this was a practical question), the proper course was to appeal to the principle of utility. ${ }^{16}$ The confounding of the roles of the expositor and the censor, as Blackstone had done, would, therefore, lead either to ultra-conservatism or to anarchy: if you liked a law, you claimed that it accorded with the natural law and should be obeyed; if you disliked it, you claimed that it did not accord and should be disobeyed.

Having said that, for Bentham, the whole purpose of the utilitarian legislator was to align law as it is with law as it ought to be. He divided the role of the expositor 'into two branches: that of history, and that of simple demonstration'. Hence, the expositor might deal with the state of the law at some point in the past or with the state it was in at the time of writing. The latter included 'the several businesses of arrangement, narration and conjecture'. Narration was the description of the law where it was 'explicit, clear, and settled', while conjecture or interpretation was where it was 'obscure, silent, or unsteady'. Bentham's main interest in A Fragment on Government, however, was with the question of arrangement, which was concerned with general denomination - that is, with the distribution of legal terms under general headings. There were two sorts of arrangement: the technical and the natural. Blackstone had provided 'an arrangement of the elements of Jurisprudence, as wants little, perhaps, of being the best that a technical nomenclature will admit of', but a technical arrangement would always be 'confused and contradictory'. The point became clear when a technical was compared with a natural arrangement. The latter took the property in actions that "men in general are, by the common constitution of man's nature, disposed to attend to', namely 'the tendency ... to, or divergency ... from' the promotion of happiness, in other words from their tendency to promote utility. Hence the principle of utility would

15 Blackstone 1765-9: i. 39-43. ${ }^{16}$ Bentham 1977: 482-3. 
preside over and govern, as it were, such arrangement as shall be made of the several institutions or combinations of institutions that compose the matter of this science .... Governed in this manner by a principle that is recognized by all men, the same arrangement that would serve for the jurisprudence of any one country, would serve with little variation for any other.

The leading terms in a natural arrangement of jurisprudence would be offences, which were actions that were prohibited because of their mischievousness. A bad law was one that prohibited an action that was not mischievous, but, within a natural arrangement, it would be 'impracticable' to designate the action in question as an offence without making an assertion that would be 'contradicted by experience'. While it would be difficult to find a place for a bad law in a natural arrangement, a technical arrangement was 'a sink that with equal facility will swallow any garbage that is thrown into it'. A natural arrangement would align the law as it is with law as it ought to be: it would 'at once be a compendium of expository and of censorial Jurisprudence'. The terms that stood at the head of a synopsis of natural jurisprudence, given their relationship to happiness and hence in turn to pain and pleasure, would 'belong rather to Ethics than to Jurisprudence'. In contrast, names of classes that were 'purely technical', such as 'offences ... against prerogative, with misprisions, contempts, felonies, præmunires', which Blackstone had incorporated into his Analysis of the Laws of England, ${ }^{17}$ but which bore no relation to the 'common end' of happiness, would either be 'banished' from a natural arrangement or placed in 'the corners and bye-places' where, instead of appearing to give, they might receive, elucidation. ${ }^{18}$

\subsection{Universal Expository Jurisprudence}

In 1780-2, Bentham devoted much of his time to composing an introduction to a proposed major work that he described as 'a plan of a penal code in terminis'. ${ }^{19}$ The first sixteen chapters and the first two sections of the seventeenth chapter of this introduction, though written and printed in 1780, were eventually published as An Introduction to the Principles of Morals and Legislation in 1789. The seventeenth chapter, entitled 'Of the Limits of the Penal Branch of Jurisprudence', had grown into a book-length

\footnotetext{
17 Blackstone 1771: [xii]. ${ }^{18}$ Bentham 1977: 414-18. ${ }^{19}$ Bentham 1970a: 1.
} 
study in its own right, and, apart from these first two sections, was never published by Bentham himself. ${ }^{20}$ In the second section, entitled 'Jurisprudence, its branches', Bentham further developed his distinction between law as it is and law as it ought to be. He presented the distinction as one within jurisprudence, that is, within the study of law, and one that was grounded in his theory of logic and language. Having stated that 'Jurisprudence is a fictitious entity', he went on to say that, in order to understand what the word jurisprudence meant, it was necessary to accompany it 'with some word that shall be significative of a real entity'. The way to do this, Bentham explained, was to talk about 'a book of jurisprudence', with the 'book' being the real entity through which the fictitious entity 'jurisprudence' could be understood. As we will see, the name of a fictitious entity represented an abstraction, while the name of a real entity represented a body with physical substance. Bentham reiterated the distinction between the expositor and the censor that he had made in A Fragment on Government:

A book of jurisprudence can have but one or the other of two objects: 1 . To ascertain what the law is: 2. To ascertain what it ought to be. In the former case it may be stiled a book of expository jurisprudence; in the latter, a book of censorial jurisprudence; or, in other words, a book on the art of legislation. ${ }^{21}$

He thereupon made several further distinctions within books of expository jurisprudence. The first distinction was between books of authoritative and unauthoritative jurisprudence, depending respectively upon whether it was the work of the legislator himself or the work of any other person. The second distinction was between books of local and universal jurisprudence, depending respectively upon whether it dealt with the laws of a particular nation or group of nations or those of 'all nations whatsoever'. The latter would have a very particular focus. No two nations had laws that were throughout exactly the same in substance, and even where the laws of the two nations agreed to some extent in substance, they would certainly not be expressed in exactly the same words and often would not 'have so much as a single word in common'. Yet, remarked Bentham, 'among the words that are appropriated to the subject of law, there are some that in all

\footnotetext{
20 The text was first published in Bentham 1945, then in Bentham 1970b, and most recently in Bentham 2010.

21 Bentham 2010: 16 .
} 
languages are pretty correspondent to one another: which comes to the same thing nearly as if they were the same. Of this stamp, for example, are those which correspond to the words power, right, obligation, liberty, and many others.'

Hence, a book of universal expository jurisprudence could not be authoritative, since there was no legislator with the power to enact laws that were valid throughout the world; nor could it be unauthoritative as far as the substance of the law was concerned, since there existed no universal laws for the legal commentator to describe. The only possible subjectmatter for universal expository jurisprudence, therefore, was the form of the law - in other words, it could deal only with 'the import of words: to be, strictly speaking, universal, it must confine itself to terminology'. ${ }^{22}$ In contrast, as Bentham had explained in A Fragment on Government, there was much greater scope for universality in relation to censorial jurisprudence, since there were 'some leading points ... in respect of which the laws of all civilized nations might, without inconvenience, be the same'. ${ }^{23}$

For the publication of An Introduction to the Principles of Morals and Legislation in 1789, Bentham composed a 'Preface', in which he explained the provenance of the text and the factors that had delayed its publication. He went on to give an account of the scope of the proposed introduction to his penal code. It would contain ten parts, the first nine of which would deal with the principles of legislation in various branches of law. The tenth part would consist of the following:

Plan of a body of law, complete in all its branches, considered in respect of its form; in other words, in respect of its method and terminology; including a view of the origination and connexion of the ideas expressed by the short list of terms, the exposition of which contains all that can be said with propriety to belong to the head of universal jurisprudence.

In a note, he added: 'Such as obligation, right, power, possession, title, exemption, immunity, franchise, privilege, nullity, validity, and the like. ${ }^{24}$ Bentham's point was that each legal system had its own terms for entities that could be found in every other legal system, and that a sensible exposition could be offered for each of those terms. This was the task of universal expository jurisprudence. Bentham's notion of universal expository jurisprudence appears to equate to the morally neutral description of

\footnotetext{
22 Bentham 2010: 16-17. ${ }^{23}$ Bentham 2010: 17-18. ${ }^{24}$ Bentham 1970a: 6 and n.
} 
a legal system that characterised Hart's methodological legal positivism. Bentham, moreover, located universal jurisprudence as a branch of the study of law as it is, which appears to confirm Hart's view of the structure of Bentham's legal theory. A closer examination of Bentham's universal expository jurisprudence, however, shows him to have been engaged in a very different exercise from that which Hart ascribed to him.

\subsection{The Key to Universal Expository Jurisprudence}

Bentham had worked out a method of exposition for abstract terms in general, and hence for legal abstract terms in particular, and thereby to accomplish the task of universal expository jurisprudence, in manuscripts written in the mid-1770s and headed 'Preparatory Principles'. ${ }^{25}$ This material, which was related both to Bentham's critique of Blackstone and to his attempt to draft a complete penal code, constituted, as it were, a storehouse of ideas on which he drew when composing his more systematic texts in the mid-to-late 1770s and early 1780s. At various points in this material, Bentham suggested titles for a book or perhaps a series of books dealing with jurisprudence in general. One such title was 'A Key to Universal Jurisprudence', ${ }^{26}$ reflecting the fact that many passages in 'Preparatory Principles' are concerned with the exposition of abstract legal terms, the subject-matter of universal expository jurisprudence. The 'key' to unlocking the mystery of legal terminology consisted in demonstrating the relationship between legal discourse and the physical world. Bentham adopted the word 'metaphysics' to represent 'that science which teacheth the signification of words, and [the] origination of the ideas which they signify'. The task of exposition was accomplished when 'the idea annext to any one word' was distinguished from 'the idea annext to any other' and when it had been shown 'how all the ideas we have that are complex, arise from, and are made up of, simple ones'. ${ }^{27}$ Every science had its 'leading terms', which were used in order to make other terms understood. The metaphysics of the science of law consisted 'in ascertaining the meaning, in fixing [the] ideas, belonging to the several terms of universal

\footnotetext{
25 See Bentham 2016. The text consists of a series of passages, ranging from one or two lines in length through to several pages, on various aspects of jurisprudence.

26 Bentham 2016: 365. ${ }^{27}$ Bentham 2016: 265.
} 
Jurisprudence, through the medium of which the technical terms of the particular Jurisprudence of any country are endeavoured to be explained'. ${ }^{28}$

The method of exposition traditionally adopted by lawyers was 'the old method per genus et differentiam', but, argued Bentham, attempts to define abstract terms, such as 'Power, Possession, Property, etc. in Morals: Ratio, Part, Multiple, etc. in Mathematics', by such means were doomed to failure because the terms in question had no superior genus to which they could be referred. The best that could be done was to provide a synonym, but often that only made matters worse. The terms characteristic of universal jurisprudence, such as power and right, had no superior genus by which they could be made known. If you heard the word cacalianthemum, and wanted to know the meaning of it, you would be told that a cacalianthemum was a sort of plant, and that would give you some idea of the import of the word. A right or power, however, was not a sort of anything. The expositors who used 'the old method', nevertheless, pursued their 'routine' and attempted to find a higher genus: 'The consequence is they either take up such a definition as is useless, or give up altogether the task of finding one, as being either unnecessary or impracticable. 'Tis by this means that so many words, of a sort that want it most, have either no definition at all, or such an one as is worse than none. ${ }^{29}$ The failure to explain the meaning of words by definition per genus et differentiam did not mean that the attempt was hopeless. The problem lay not with 'the science itself' but in the method that had hitherto been employed. There was 'but one way' that could be successful, though it was a method that "never has been attempted yet'. 30

Bentham's new approach was based on the view that abstract terms could only be understood by reference to simple ideas and that simple ideas were derived from physical objects that were perceived by the senses. He credited John Locke with the insight that "[a] discourse containing words in it meant to convey complex ideas is never made intelligible, till the simple ideas involved in those complex ones are made assignable', ${ }^{31}$ but he went beyond Locke in his account of the role of language in this process. The clarification of the import of an abstract term, stated Bentham, required more than a single definition, but rather 'a chain of Definitions' in

${ }^{28}$ Bentham 2016: 196-7. ${ }^{29}$ Bentham 2016: 97-8, 111-12. ${ }^{30}$ Bentham 2016: 157.

31 Bentham 2016: 75. See Locke 1975: 292. 
which the first consisted of "words expressive of simple ideas'. ${ }^{32}$ Again he stated, 'No Definition can be a good one, unless it either come home to simple ideas, or fit into an uninterrupted chain of other Definitions of which the first link does. ${ }^{33}$ Simple ideas were those by which 'sensible images' were impressed on the mind and consisted of events and situations: events were bodies in motion, while situations were bodies at rest. ${ }^{34}$ Everything that was perceived by 'our exterior senses' was constituted by matter and motion, but motion was itself a quality of matter, and not something distinct: hence, '[w] hether there be motion in any case or whether there be none, it is still matter and matter only that exists' ${ }^{35}$ In short, the sole source of simple ideas was matter, which was distributed into different bodies. The distinction between one single body and another between one individual and another - was not an objective feature of the physical world but a construct of the perceiving mind. Matter could be divided almost without limit, and there was no objective way of determining what should be deemed a single body and what several bodies. The same was true of the distinction between one act and another. There was no objective way of determining what should be deemed a single act and what several. 'There is no body that can for any purposes be spoken of as a whole', stated Bentham, 'but what may to other purposes, with equal propriety, be spoken of as distinguished into parts. There is no quantity of motion, therefore, that can be spoken of as one act, but may with equal propriety be spoken of as several acts.' The individual body and the individual act were a product of language: 'What determines a portion of matter to be spoken of as one is unity of name. What determines a quantity of motion to be spoken of as one is, in like manner, unity of name. ${ }^{36}$ Bentham summarised his position as follows: 'The existences that fall within the cognizance of our senses are comprizable in a single appellative,

32 Bentham 2016: 104.

33 Bentham 2016: 141. See also Bentham 2016: 119: 'Simple ideas are the ne plus ultra of expository investigation: the mind neither can go deeper in its researches, nor has occasion. He who cannot understand a word when the explanation of it is rightly conducted upon that plan, can never.'

34 Bentham 2016: 169.

35 Bentham 2016: 369. Bentham distinguished the object and the perception. In strictness, we did not see an object itself but the rays of light that issued from it. Similarly, we did not smell an object itself but its 'odorous particles'. See Bentham 2016: 126. For motion as a property of matter, see Bentham 2016: 169-70.

36 Bentham 2016: 395. 
Bodies. What is common to all these Bodies is that they are either in a state of rest, or in a state of Motion.' The only things that were perceptible to our senses, in other words the only things that could be said to have existence, were bodies. ${ }^{37}$ In other words, names were invented to demarcate these bodies and such names represented simple ideas.

Bentham went on to point out that such entities as golden mountains, diamond billiard balls and sphinxes, which did not exist in reality and yet constituted ideas in the mind, were very different in nature from the fictitious entities that formed the subject-matter of universal jurisprudence. We could take any figure or shape that we had seen and associate it with any colour that we had seen, even though we had never seen that figure and colour associated in nature,

and thus form ideas of imaginary substances at pleasure .... A Diamond Billiard Ball is what I have never seen: but I have seen a Diamond, and I have seen a Billiard Ball. A Diamond Billiard Ball is, therefore, what I can imagine. Though I never have had the substance of a Diamond Billiard Ball before my eyes, I can have, I now have, the idea of it in my mind. ${ }^{38}$

Such a combination of simple ideas produced what Bentham termed a fabulous entity. Hence, in the course of composing 'Preparatory Principles', Bentham settled on the terminology that he would apply throughout the remainder of his career - noun substantives might signify entities that were real, fictitious or fabulous. The names of real entities represented bodies existing in the physical world: 'The only objects that really exist are substances: they are the only real entities.' The names of fictitious entities represented entities that did not actually exist in the physical world but were spoken of as if they did exist: 'To convey any notion by words which are the names of any objects [other] than substances, we are obliged to attribute to such objects what in truth is attributable only to substances: in a word, we are obliged to feign them to be substances. Those others, in short, are only fictitious entities. ${ }^{39}$ Fictitious entities, though given names that 'in strictness' were 'proper only for real beings, viz: substantives', were not to be considered as 'being represented seriously as existing', but were rather 'feigned' to exist 'merely for the

37 Bentham 2016: 397. See also Bentham 2016: 395, where Bentham suggested that mental processes were reducible to matter: 'Even in an act of the mental kind, some distinguishable, assignable portion of matter is necessarily concerned.'

38 Bentham 2016: 169-71. 39 Bentham 2016: 424. 
purposes of discourse'. The names of fictitious entities included 'Liberty, Right, Condition, Quality, disposition, etc.'. The names of fabulous entities were combinations of real entities assembled by the imagination but which did not exist in such combinations in the physical world. ${ }^{40}$

Given that any chain of definitions had to begin with simple ideas, that is, those images in the mind created by bodies that were immediately perceptible, and were not themselves definable, it followed that ' $t$ the origin of our ideas relative to Law can, therefore, be sought for in no other source'. ${ }^{41}$ The problem with the leading terms found in law was that, as noted, they were 'nothing'. Legal powers, for instance, were 'not to be defined. They belong to no genus. Take them by themselves, no notion is to be formed of them at all. The words are Substantives: but they are not names of substances ... they are not names of any thing[s] that exist.' To define power, like right and wrong, as a single word was 'impossible'. Rather, a term such as 'power' had to be placed in a sentence, or more precisely in a proposition.

This proposition may be translated into another proposition that is equivalent: and that is composed of words which, taken separately, shall either be capable of a definition, or what is still better, need none. To create a power in a person over a thing, or what is shorter and more familiar, to give a person a power over a thing, is to restrain another person from meddling with that thing, the first person being left unrestrained. ${ }^{42}$

Referring to the names of real entities as proper noun substantives and the names of fictitious entities as improper, Bentham stated:

A proper substantive, the name of a real entity, is understood immediately and of itself it offers a certain image to the conception. An improper substantive offers no such image. Of itself it has no meaning. It means nothing till, with other words, it be compounded into some sentence. It then is seen to have a meaning, which is the clearer, the more clearly it is seen to be equivalent to some sentence the terms of which are names of real entities. ${ }^{43}$

As well as external bodies in motion and at rest, simple ideas included pain, pleasure and volition:

These [words] nobody defines, or if any one defines, nobody makes clearer by defining. They need not be defined, they can not. For to define a word is to point

\footnotetext{
40 Bentham 2016: 387. ${ }^{41}$ Bentham 2016: 200. ${ }^{42}$ Bentham 2016: 380.

43 Bentham 2016: 401.
} 
out, in some way or other the simple ideas that go to the composing of the more complex idea of which usage has made that word the sign. But of these, each is the sign of one simple idea, and no more.

The meaning of terms signifying simple ideas was grasped directly from perception, and this was where the attempt to expound the terms that belonged to universal jurisprudence would begin. It was by relating the terms of universal jurisprudence to terms that signified simple ideas that the former terms would be understood. 'These [simple ideas] are the Capital we have to trade with. These, to speak with the Algebraists, are our known quantities, our $a$ 's, $b$ 's and c's. 'Tis by reference to these that we are to elicit the import of the $x$ 's, $y$ 's and $z$ 's, whose import there is occasion to make known. ${ }^{44}$

Bentham referred to this technique of translating propositions as paraphrasis and claimed that it was the only means by which the names of fictitious entities could be expounded: 'To expound an improper substantive by Paraphrasis is to compleat it into a sentence, and for that sentence to find an equivalent sentence consisting of words significative of real entities. ${ }^{45}$ In order to understand what was meant by the word right, for instance, it had to be included in a sentence, and that sentence expounded 'by such another sentence as contains in it words that are capable of being defined'. ${ }^{46}$ The word right was a noun substantive, but it did not signify a substance, neither a 'real concrete' nor a 'fictitious abstract' substance (that is a fabulous entity), and hence was no more significant of itself than a preposition such as the word 'for': 'Who is there that ever supposed it possible to define "for"? No man. As little is it possible to define "a right".' In order to understand the word 'for', it was necessary to bring forward a sentence in which the word appeared, and the same was true in relation to the word 'right'. ${ }^{47}$ When Bentham gave the following example of paraphrasis in A Fragment on Government, he was drawing on the 'metaphysics' that he outlined in 'Preparatory Principles':

A word may be said to be expounded by paraphrasis, when not that word alone is translated into other words, but some whole sentence of which it forms a part is translated into another sentence; the words of which latter are expressive of such

\footnotetext{
44 Bentham 2016: 102-3. $\quad{ }^{45}$ Bentham 2016: 386. $\quad{ }^{46}$ Bentham 2016: 247.

47 Bentham 2016: 249.
} 
ideas as are simple, or are more immediately resolvable into simple ones than those of the former.

There was no other method that could explain the meaning of "the words duty, right, power, title, and those other words of the same stamp that abound so much in ethics and jurisprudence'. A person had a legal duty to perform an action when another person had a right to have him be made to do it. In other words, the person under the duty was liable to be punished at law for not performing the action, and to be punished in this way meant suffering a pain inflicted by command of the lawmaker. The abstract term duty was, therefore, placed in a proposition, and that proposition was translated into a proposition with the same meaning but which referred to real entities - in this case such real entities as persons, pains and expressions of will. ${ }^{48}$

Once terms had been properly expounded, claimed Bentham, many jurisprudential puzzles would be solved: 'The words defined are all so many given quantities, and possessing which, the Jurist finds himself rich in means for the solution of any problem in his science. ${ }^{49}$ Indeed, once terms were properly expounded, their meaning would be 'fixed for ever' ${ }^{50}$ It might, however, be necessary to invent new words in order to represent any new ideas generated, since "the words of the current stock are, many of them, stuffed and crammed with three or four ideas stuck in them at once'. ${ }^{51}$ In the course of 'Preparatory Principles', Bentham identified several benefits that would result from the creation of a science of universal expository jurisprudence. One benefit was that it would bring an end to disputes of law as opposed to questions of fact: 'All Questions of Law are no more than questions concerning the import of words. Questions the solution of which depends upon skill in Metaphysics. As that master science, therefore, advances to it's [sic] perfection, this source of litigation will be contracted. ${ }^{52}$ Unless the words used in law had a clear meaning, they could not fulfil the function of law, which was to guide conduct. 'Words, to be of use, must serve for signs to our ideas, must serve to excite precise ideas in the minds of those that hear them. A text that will not serve

48 See Bentham 1977: 494-5 n. $\quad{ }^{49}$ Bentham 2016: $223 . \quad{ }^{50}$ Bentham 2016: 278.

51 Bentham 2016: 254. See also Bentham 2016: 361: 'No department of science can receive any considerable improvement but the language must receive a new modification. New ideas struck off from the general mass must, like the old ones, have words of their own to dress them in. These words must be, in some sort, new.'

52 Bentham 2016: 282. 
to call up precise and distinct ideas, such a text, in the instances where it fails of doing so, will not serve for any thing. ${ }^{53}$ It was only by 'Metaphysics' - through clear exposition - that 'controverted points in Law can be clearly solved'. ${ }^{54}$ Bentham referred to the dispute with the American colonists as evidence of the importance of words: 'A great part of the merits of the American controversy, as far as concerns the matter of right, centers on the signification of the words Give, grant, consent, representation, taxation, legislation, constitution. ${ }^{55}$ Bentham's point was that disputes arose from competing definitions of legal terms - once a settled exposition had been given, there would be no basis for disagreement insofar as legal terminology was concerned.

A second benefit was that sensible communication would be established between jurists of different nations:

By banishing as many as we can spare of the terms peculiar to our own local Jurisprudence, and giving a clear and steady exposition of such as we are obliged to retain in terms of universal jurisprudence, an easy and profitable intercourse may be kept up between the Jurists of the several nations, and an Englishman might read a comment upon his own laws in the languages of Spain or Sweden. ${ }^{56}$

'[A]n expository treatise on the Laws of England written in terms of universal jurisprudence,' noted Bentham, 'couched in untechnical universal language, at the same time that it is a key to the Laws of England, is a Key to the Laws of any other country.' It would then be a relatively straightforward matter to apply it elsewhere:

To the Laws of England, it is a key, ready fitted to the lock. To the Laws of France, it is a key ready to be fitted into the lock, by any Artist who can enter, with a tolerable degree of facility, into the views of him that made it. A work written on this plan, even upon the Laws of our Island, would bear translation into the languages of the continent. $^{57}$

A third benefit was that, by giving 'paraphrases' of 'the several sorts of fictitious legal entities - Powers over persons, over things; over persons Rights to services - Protection etc.', not only would Bentham be able to use these terms in his own work but he would also clarify their meaning when used by other writers. ${ }^{58}$

\footnotetext{
53 Bentham 2016: 106. $\quad{ }^{54}$ Bentham 2016: 265. $\quad{ }^{55}$ Bentham 2016: 266.

56 Bentham 2016: 260. ${ }^{57}$ Bentham 2016: 138-9. $\quad{ }^{58}$ Bentham 2016: 344-5.
} 


\subsection{Moral Neutrality}

Did Bentham separate fact and value and hence commit himself to substantive legal positivism, and did he intend that his universal expository jurisprudence should lead to the production of a vocabulary of morally neutral terms and hence commit himself to methodological legal positivism? In other words, did the conceptual separation of fact and value underpin Bentham's distinction between law as it and law as it ought to be, and did universal expository jurisprudence, therefore, belong to the domain of (morally neutral) fact? The answer to both questions is in the negative and for the same reason - namely, the particular form of Bentham's utilitarianism and its relationship to his psychological theory, both of which were grounded in the naturalistic ontology discussed in Section 9.4.

In later writings, Bentham emphasised the point that logic (the term that he came to use instead of 'metaphysics') was, far from being a morally neutral activity, crucial to well-being or happiness - in other words, to the promotion of utility. In his essay on 'Logic', he explicitly linked the clarification of terminology - which was the task of universal expository jurisprudence - to the promotion of utility. He defined logic as 'the art, which has for its object or end in view, the giving to the best advantage, direction to the human mind and thence to the whole human frame, in its pursuit of any object or purpose, to the attainment of which it is capable of being applied'. ${ }^{59}$ He went on to state that, '[o]f the art and science of logic, the prime and that the most immediate use is the establishment of clear and determinate ideas', and that this objective would be achieved through such operations as methodisation, distinction, definition, division and exposition. ${ }^{60}$ Given that the pursuit of well-being was 'the end of every action', logic had the same end. ${ }^{61}$ Again, in The Book of Fallacies, he noted that '[b]y Logic taken at large may be understood the art of applying to best advantage to the purpose of discourse the faculty of discourse', and referred to it as 'this all-comprehensive art and science'. ${ }^{62}$ As we have seen, when discussing universal expository jurisprudence in 'Preparatory Principles', Bentham drew attention to the benefits that would accrue from

\footnotetext{
59 UCL Bentham Papers, box ci, fo. 92 (3 August 1814).

60 UCL Bentham Papers, box ci, fo. 103 (5 August 1814).

61 UCL Bentham Papers, box ci, fo. 107 (25 September 1815). $\quad{ }^{62}$ Bentham 2015: 408 n.
} 
an accurate definition of terms. In similar vein, the final section of of the Limits of the Penal Branch of Jurisprudence was entitled 'Uses of this chapter'. Bentham marked each 'use' according to whether it belonged to 'form' or to 'matter', that is, whether it belonged to expository or to censorial jurisprudence. Both enterprises were justified by their utility. ${ }^{63}$ Finally, given Bentham's theory of motivation, in which no action was undertaken except with a view to experiencing pleasure or averting pain, no one would be motivated to undertake the task of either censorial or expository jurisprudence unless they expected to gain some benefit, and hence some pleasure, in performing it. There was no such thing as an unmotivated action. ${ }^{64}$ The expected pleasure might arise from the satisfactory completion of a difficult intellectual enterprise, from the gaining of knowledge, from the hope of benefiting one's community or humanity in general, or merely because one was paid to do it. As Bentham stated in his essay on 'Logic': 'Desire of pleasure and of exemption from pain, in one word interest, [are] in some shape or other the source of every thought as well as the cause of every action, and, in particular, of every action by which names are employed in the designation of persons and of things. ${ }^{65}$ Every action was motivated by a desire for pleasure and an aversion to pain, and every action had consequences in terms of promoting pleasure and avoiding pain - and wherever pleasure and pain was involved, so was morality. There was no space for moral neutrality.

It should be emphasised that Bentham put forward a unified theory: there was only one physical world, and hence only one source of experience and of knowledge. Fact and value did not belong to separate or separable domains. ${ }^{66}$ On the one hand, for Bentham, a statement of value was a statement of fact. A statement of value only made sense insofar as it was resolved by paraphrasis into a statement about the existence of the real entities of pain and pleasure - it was a statement about a matter of fact in the physical world. On the other hand, a statement of fact, insofar as it was true, was of positive value because it told us something worth knowing about the state of the physical world, and, conversely, insofar as it was false, of negative value because it misled us about the state of the physical

63 Bentham 2010: 219-33. ${ }^{64}$ Bentham 1983b: 87, 98-9, 112.

65 UCL Bentham Papers, box cii, fo. 42 (28 September 1814).

66 See, e.g., 'Encyclopedical Table, or Art and Science Table' in Bentham 1983a: between 178 and 179, where the whole field of knowledge appears under the joint headings of 'being' and 'well-being'. 
world. The statement of what the law is, therefore, while a statement of fact, consisted of useful knowledge and hence was valuable, and no one would be motivated to make any investigation into what the law is unless they expected some benefit to arise from doing so. Bentham's ontology did not allow for that carving up of experience into a physical world of morally neutral fact and a transcendent world of value that seems to be required by Hart's notion of the separation of fact and value.

It might be argued in response that Bentham criticised the use, in the description of motives, of what he referred to as 'eulogistic' and 'dyslogistic' terms, which carried associations of praise and blame respectively, and instead suggested the use of 'neutral' terms. In relation to pleasures and pains of the religious sanction, for instance, eulogistic terms for corresponding motives included 'piety' and 'devotion', dyslogistic terms included 'superstition' and 'bigotry', and neutral terms included 'sense of religious duty' and 'fear of God'. He referred to eulogistic and dyslogistic terms as 'censorial' because of their connection with sentiments of approval or disapproval, which presumably meant that he regarded neutral terms as expository. He continued: 'Thus it is that, in addition to the import which, in the character of a simple term, properly belongs to it, will be found involved in every such censorial appellation the import of at least one entire proposition: viz. a proposition expressive of a judgement of approbation or disapprobation.' The problem with the use of a dyslogistic term was that any beneficial effects, and conversely with a eulogistic term any mischievous effects, tended to be ignored. ${ }^{67}$ As Bentham further explained in The Book of Fallacies, the use of these terms involved a begging of the question. The approval or disapproval of a particular practice, for instance, would depend on the associations of the term by which it was described, rather than on its substantive utility. Moreover, the very choice of term would be motivated by some interest: for instance, if one wished to disparage a certain person, one would choose a dyslogistic term to describe that person. It was, therefore, conducive to utility to adopt terms that were neutral in relation to the ideas that were associated with them. ${ }^{68}$ But neutral terminology did not, for Bentham, imply moral neutrality. While he advocated a vocabulary that did not carry 'censorial' associations, he did so not because such a vocabulary would be morally

67 See Bentham 1983b: 83, $95 . \quad{ }^{68}$ Bentham 2015: 315-18, $322 \mathrm{n}$. 
neutral but because it would promote utility - in other words, it would be valuable.

It is worth drawing attention to two short passages that illustrate the point that Bentham did not subscribe to Hart's conceptual separation of law and morality. First, in Letters to Count Toreno (1822), having discussed the principles on which a penal code ought to be grounded, Bentham stated: 'Thus, not only in a direct way, by the application made of it to each particular case, but in an additional way by means of the method to which it gives birth, does the principle of the greatest happiness of the greatest number, cover the whole field of legislation with its salutary influence.' Hence, 'the whole field' - which included both the content of the law and the method by which it was organised, the subject-matters of censorial and universal expository jurisprudence, respectively - was subject to the principle of utility. ${ }^{69}$ Second, in notes for 'Table of the Springs of Action' (1817), Bentham wrote: 'Principles of utility two, or if but one, it is understood in two senses - viz. the censorial and the expositive or exhibitive. ${ }^{70}$ Expository jurisprudence - identification of what the law is - and censorial jurisprudence - recommendation of what the law ought to be - were both aspects of the principle of utility. The gloss put upon Bentham's distinction between what the law is and what the law ought to be by Hart was a product of his commitment to the separation of fact and value, but such a separation had no place in Bentham's thought because a statement of value was also a statement of fact, and there was no statement of fact that did not have value, whether positive or negative. For Bentham, the distinction between law as it is and law as it ought to be did not represent the distinction between fact and value that characterised substantive legal positivism, but rather a distinction between an actually existing state of affairs (whether past or present) and a proposed state of affairs, with the latter being deemed more valuable in terms of its utility than the former. For Bentham, universal expository jurisprudence was not the attempt to conduct legal theory in the morally neutral terms that characterised methodological legal positivism; it was an attempt to find stable, sensible and hence useful expositions of abstract legal terms in order to advance legal science and thereby facilitate the construction of

69 Bentham 2012: 208.

70 See Bentham 1983b: 9. The 'notes' in question were copies of summaries of the main text that Bentham wrote in the margin. The relevant text sheet is missing. 
a utilitarian code of laws. For Bentham, both enterprises were value-laden. Seen through the lens of Hart's twentieth-century philosophy, Bentham's legal theory may plausibly appear to open the legal positivist tradition, but to ascribe legal positivism to the historical Bentham is an anachronism.

\section{References}

Bentham, J. University College London Library. Bentham Papers. Manuscript boxes i-clxxvi.

Bentham, J. 1945. The Limits of Jurisprudence Defined. Ed. C. W. Everett. Columbia University Press.

Bentham, J. 1970a. An Introduction to the Principles of Morals and Legislation. Eds.

J. H. Burns and H. L. A. Hart. Athlone Press.

Bentham, J. 1970b. Of Laws in General. Ed. H. L. A. Hart. Athlone Press.

Bentham, J. 1977. A Comment on the Commentaries and A Fragment on Government. Eds. J. H. Burns and H. L. A. Hart. Athlone Press.

Bentham, J. 1983a. Chrestomathia. Eds. M. J. Smith and W. H. Burston. Clarendon Press.

Bentham, J. 1983b. Deontology together with A Table of the Springs of Action and Article on Utilitarianism. Ed. A. Goldworth. Clarendon Press.

Bentham, J. 1998. 'Legislator of the World': Writings on Codification, Law, and Education. Eds. P. Schofield and J. Harris. Clarendon Press.

Bentham, J. 2010. Of the Limits of the Penal Branch of Jurisprudence. Ed. P. Schofield. Clarendon Press.

Bentham, J. 2012. On the Liberty of the Press, and Public Discussion and Other Legal and Political Writings for Spain and Portugal. Eds. C. Pease-Watkin and P. Schofield. Clarendon Press.

Bentham, J. 2015. The Book of Fallacies. Ed. P. Schofield. Clarendon Press.

Bentham, J. 2016. Preparatory Principles. Eds. D. G. Long and P. Schofield. Clarendon Press.

Blackstone, W. 1765-9. Commentaries on the Laws of England. 4 vols. Clarendon Press.

Blackstone, W. 1771. An Analysis of the Laws of England. 6th ed. Clarendon Press. Hart, H. L. A. 1982. Essays on Bentham: Studies in Jurisprudence and Political Theory. Clarendon Press.

Hart, H. L. A. 1996. 'Bentham's Principle of Utility and Theory of Penal Law'. In J. Bentham. An Introduction to the Principles of Morals and Legislation. Eds. J. H. Burns and H. L. A. Hart. Introduction by F. Rosen. Clarendon Press: lxxixcxii.

Hume, D. 2007. A Treatise of Human Nature: A Critical Edition. 2 vols. Eds. D. F. Norton and M. J. Norton. Clarendon Press. 
Lieberman, D. 1989. The Province of Legislation Determined: Legal Theory in Eighteenth-Century Britain. Cambridge University Press.

Locke, J. 1975. Essay Concerning Human Understanding. Ed. P. H. Nidditch. Clarendon Press.

Perry, S. R. 2001. 'Hart's Methodological Positivism'. In J. Coleman (ed.). Hart's Postscript: Essays on the Postscript to the Concept of Law. Oxford University Press: 311-54.

Postema, G. J. 1986. Bentham and the Common Law Tradition. Clarendon Press.

Schofield, P. 2010. 'Jeremy Bentham and HLA Hart's "Utilitarian Tradition in Jurisprudence”. Jurisprudence 1: 147-67. 